\title{
Pengaruh Inventarisasi, Legal Audit, Penilaian dan Kondisi Aset terhadap Optimalisasi Pemanfaatan Aset pada Pemerintah Daerah Kabupaten Bone Bolango
}

\author{
SHERLY $^{1}$, HERMAN KARAMOY ${ }^{2}$, HENDRIK GAMALIEL ${ }^{3}$
}

\author{
${ }^{1,2,3}$ Program Studi Magister Akuntansi, Fakultas Ekonomi dan Bisnis Universitas Sam Ratulangi \\ email: sherlypauweni@yahoo.co.id, hkaramoy@yahoo.com, hendrik_gamaliel@unsrat.ac.id
}

\begin{abstract}
One of the main problems in the asset management is the asset utilisation and management disorders. This creates difficulties for the local government to identify the assets that they hold or manage, thus the asset utilisation and its management tend not to be optimal. The objective of this research is to analyse the impact of asset management to the optimisation of the asset utilisation at Local Government of Bone Bolango. The variables utilised for this research are stocktaking, legal auditing, assessment and condition of the asset. The samples for this research are 104 people. Respondents were selected through purposive sampling. This is a quantitative research and the method used was multiple regression analysis. The research finding shows that partially, the stocktaking, assessment and condition of the asset have positive and significant impact to the optimisation of asset utilisation; while the legal auditing has no impact toward the optimisation of asset utilisation. The value of the coefficient of determination shows that the stocktaking, legal auditing, assessment and condition of the asset altogether contribute to the optimisation of asset utilisation which is $58,8 \%$ and the remaining of $41,2 \%$ is affected by the factors beyond this research.
\end{abstract}

Keywords: The Optimization of Asset Utilisation, Stocktaking, Legal Auditing, Assessment, and Condition of the asset.

\begin{abstract}
Abstrak. Salah satu masalah utama dalam manajemen aset adalah ketidaktertiban dalam penggunaan dan pemanfaatannya. Ini menyebabkan pemerintah daerah kesulitan untuk mengetahui secara pasti aset yang dikuasai atau dikelolanya, sehingga aset-aset tersebut cenderung tidak optimal dalam penggunaan maupun pemanfaatannya. Penelitian ini bertujuan untuk menganalisis pengaruh manajemen aset terhadap optimalisasi pemanfaatan aset pada Pemerintah Daerah Kabupaten Bone Bolango. Variabel-variabel yang digunakan dalam penelitian ini adalah inventarisasi, legal audit, penilaian dan kondisi aset. Dengan menggunakan purposive sampling, jumlah sampel penelitian yang diambil sebanyak 104 orang. Jenis penelitian ini adalah kuantitatif dengan menggunakan metode analisis regresi berganda. Hasil penelitian menunjukkan bahwa secara parsial inventarisasi, penilaian dan kondisi aset berpengaruh positif dan signifikan terhadap optimalisasi pemanfaatan aset, sedangkan legal audit tidak berpengaruh terhadap optimalisasi pemanfaatan aset. Nilai dari koefesien determinasi menunjukkan bahwa inventarisasi, legal audit, penilain dan kondisi aset bersama-sama berkontribusi terhadap optimalisasi pemanfaatan aset yaitu sebesar 58,8\%, dan sisanya 41,2 \% dipengaruhi oleh faktor lain diluar model penelitian.
\end{abstract}

Kata kunci: Optimalisasi Pemanfaatan Aset, Inventarisasi, Legal Audit, Penilaian dan Kondisi Aset

\section{Pendahuluan}

Aset daerah adalah unsur yang penting dalam rangka penyelenggaraan pemerintahan dan pemberian layanan kepada publik. Aset daerah harus dikelola secara baik dalam hal pemanfaatannya, efisien dan efektif dalam perencanaan dan pendistribusiannya, transparan dan akuntabel dalam penyajian, pelaporan dan pengawasannya. Selain itu, aset daerah juga merupakan pilar utama sebagai pendapatan asli daerah, sehingga pemerintah daerah (Pemda) sangat dituntut dalam hal pengelolaan aset daerah yang baik, khususnya mengenai pengelolaan dan pemanfaatan aset yang optimal.

Pengelolaan aset daerah diatur dalam Peraturan Pemerintah (PP) Republik Indonesia Nomor 6 Tahun 2006 tentang Pengelolaan Barang Milik Negara/Daerah. PP tersebut ditindaklanjuti dengan Peraturan Menteri Dalam Negeri (Permendagri) Republik Indonesia Nomor 17 Tahun 2007 tentang Pedoman Teknis Pengelolaan Barang Milik Daerah. Adapun lingkup pengelolaan aset itu sendiri meliputi : perencanaan kebutuhan dan penganggaran, pengadaan, penerimaan, penyimpanan dan penyaluran, penggunaan, penatausahaan, pemanfaatan, pengamanan dan pemeliharaan, penilaian, penghapusan, pemindahtanganan, pembinaan, pengawasan dan pengendalian, pembiayaan, dan tuntutan ganti rugi. Salah satu kegiatan dalam pengelolaan aset adalah pemanfaatan, sebagaimana 
Permendagri Nomor 17 Tahun 2007 menyebutkan bahwa pemanfaatan merupakan pendayagunaan Barang Milik Daerah (BMD) yang tidak dipergunakan sesuai tugas pokok dan fungsi Satuan Kerja Perangkat daerah (SKPD) dalam bentuk pinjam pakai, sewa, kerjasama pemanfaatan, bangun guna serah, bangun serah guna dengan tidak merubah status kepemilikan. Pemanfaatan BMD yang optimal akan membuka lapangan kerja, meningkatkan pendapatan masyarakat, dan menambah/ meningkatkan pendapatan daerah.

Yusuf (2013:169) menyatakan bahwa untuk melakukan optimalisasi aset harus dilakukan inventarisasi, penilaian serta pengkajian terhadap potensi aset yang ada dengan menghimpun semua jenis aset, baik aset bergerak maupun aset tidak bergerak. Inventarisasi dilakukan untuk mengetahui asal usul serta informasi yang berkaitan dengan aset. Informasi yang diperoleh dari hasil inventarisasi umumnya mencakup volume, luas, jenis, spesifikasi, merk dan harga perolehan dari aset. Inventarisasi juga memberikan informasi mengenai keberadaan aset pemda, karena jumlah aset yang besar dapat memberikan kemungkinan aset yang tercatat hilang dan tidak diketahui keberadaannya ataupun aset yang jelas keberadaannya namun tidak tercatat di laporan aset milik pemda. Dengan informasi yang lengkap, jelas dan akurat mengenai aset, maka akan memudahkan pemda untuk menggunakan dan memanfaatkan aset tersebut. Selain proses inventarisasi, legal audit menjadi salah satu langkah yang dilakukan untuk mengoptimalkan pemanfaatan aset. Siregar (2004:519) menyatakan bahwa legal audit merupakan satu lingkup pekerjaan manajemen aset yang berupa inventarisasi status penguasaan aset, sistem dan prosedur penguasaan aset, identifikasi dan mencari solusi permasalahan legal, dan strategi untuk memecahkan berbagai permasalahan legal yang terkait dengan penguasaan ataupun pengalihan aset. Legal audit diperlukan setelah proses inventarisasi aset karena setiap aset yang dimiliki pemda harus jelas status kepemilikannya, untuk mencegah potensi sengketa ataupun penyerobotan dari orangorang yang tidak bertanggungjawab, yang ingin mengambil aset milik pemda. Dokumen kepemilikan aset tersebut berupa sertifikat untuk aset tanah, Izin Mendirikan Bangunan (IMB) untuk aset bangunan, Bukti Kepemilikan Kendaraan Bermotor (BPKB) untuk aset peralatan mesin khususnya kendaraan bermotor baik roda dua maupun roda empat.

Aset daerah dapat dimanfaatkan jika dalam kondisi baik dan layak untuk digunakan. Handayani (2007) menyatakan bahwa faktor kondisi aset terbukti memiliki pengaruh terhadap pemanfaatan aset. Dalam penggunaannya, aset harus dalam kondisi baik dan layak sehingga dapat mencapai hasil yang maksimal. Untuk aset daerah dengan kondisi aset yang baik dapat menunjang pelaksanaan tugas pokok dan fungsi (tupoksi) dari para pegawai sehingga dapat memberikan pelayanan publik yang baik kepada masyarakat. Selain itu kondisi aset yang baik juga dapat menarik minat pihak di luar pemda untuk melakukan sewa atau melakukan kerjasama dengan pihak pemda untuk menggunakan dan memanfaatkan aset yang ada. Manajemen aset yang sudah dilakukan oleh Pemda Kabupaten Bone Bolango sampai dengan saat ini mulai dari inventarisasi, pembenahan dokumen kepemilikan, penilaian serta penelaahan kondisi-kondisi aset tak lepas dari temuan-temuan yang sebelumnya telah disampaikan oleh Badan Pemeriksa Keuangan (BPK). Badan Pemeriksa Keuangan (BPK) umumnya menemukan beragam penyimpangan dalam hal pengelolaan aset daerah, baik dari segi penggunaan dan pemanfaatannya, mulai dari tidak akuratnya nilai aset yang dikelola, status kepemilikan aset yang tidak jelas, keberadaan aset yang tidak diketahui serta banyaknya aset yang tidak diketahui pula nilainya. Beragam permasalahan tersebut mengakibatkan pengelolaan aset daerah menjadi tidak tertib, karena tidak menggambarkan keadaaan yang sebenarnya terjadi di lapangan. Oleh karena itu pemerintah daerah perlu menyiapkan instrumen yang tepat untuk melakukan pengelolaan aset daerah secara profesional, transparan dan akuntabel mulai dari tahap perencanaan, pendistribusian, pemanfaatan serta pengawasannya.

Temuan BPK mencerminkan masih kurang tertibnya pengelolaan aset di daerah. Temuan mengenai tidak adanya bukti kepemilikan tanah tidak sesuai dengan PP Nomor 6 Tahun 2006 tentang Pengelolaan Barang Milik Daerah pada pasal 33 ayat (1) yang menyatakan bahwa barang milik daerah berupa tanah harus disertifikatkan atas nama Pemerintah Republik Indonesia/ Pemerintah Daerah yang bersangkutan. Untuk temuan aset tetap yang tidak memiliki nilai tidak sesuai dengan Permendagri Nomor 17 tahun 2007 tentang Pedoman Teknis Pengelolaan Barang Milik Daerah Lampiran Romawi $\mathrm{X}$ yang menyatakan apabila harga barang hasil pembelian, pembuatan, dan berasal dari sumbangan/ hibah tidak diketahui nilainya, maka dapat dilakukan penilaian oleh tim penaksir atau oleh penguru barang. Atas temuan-temuan tersebut di atas, BPK merekomendasikan inventarisasi untuk seluruh aset tetap agar dapat diketahui kondisinya serta berapa nilai aset yang sebenarnya sesuai dengan laporan aset yang ada. BPK juga merekomendasikan pengurusan status kepemilikan dari aset-aset daerah untuk mencegah berpindahnya penguasaan atas aset-aset daerah tersebut. Selain itu, BPK juga 
merekomendasikan proses penilaian untuk aset-aset daerah yang tidak diketahui luasan dan nilainya. Keseluruhan langkah yang direkomendasikan oleh BPK mulai dari inventarisasi, legal audit, penilaian serta pengecekan kondisi aset akan membawa aset ke arah pemanfaatan yang optimal. Aset dengan kondisi yang baik, terdata lengkap dan akurat, memiliki nilai dan status kepemilikan yang jelas akan membawa peluang penyewaan atau kerjasama dari pihak ketiga yang akhirnya dapat meningkatkan pendapatan daerah.

Penelitian mengenai pengaruh inventarisasi aset, legal audit dan penilaian aset pernah dilakukan oleh Erlini Nasution (2014) dengan judul "Pengaruh Manajemen Aset terhadap Optimalisasi Aset Rumah Sakit Jiwa Daerah Provinsi Sumatera Utara'. Hasil penelitiannya menyatakan bahwa secara parsial variabel inventarisasi aset, legal audit dan penilaian aset terbukti berpengaruh positif terhadap optimalisasi aset. Penelitian lain mengenai pengaruh kondisi aset terhadap pemanfataan aset pernah dilakukan oleh Handayani (2007) dengan judul "Faktor-faktor yang Mempengaruhi Pemanfaatan Aset Tanah dan Bangunan Gelanggang Remaja Kotamadya Jakarta Pusat". Hasil penelitiannya menyatakan bahwa faktor kondisi aset terbukti memiliki pengaruh terhadap pemanfaatan gelanggang remaja Kotamadya Jakarta Pusat.

Berdasarkan latar belakang permasalahan di atas, maka rumusan masalah dalam penelitian ini adalah sebagai berikut:

1. Apakah inventarisasi berpengaruh terhadap optimalisasi pemanfaatan aset?

2. Apakah legal audit berpengaruh terhadap optimalisasi pemanfaatan aset?

3. Apakah penilaian berpengaruh terhadap optimalisasi pemanfaatan aset?

4. Apakah kondisi aset berpengaruh terhadap optimalisasi pemanfaatan aset?

Adapun tujuan dari penelitian ini adalah untuk menguji secara empiris pengaruh inventarisasi, legal audit, penilaian dan kondisi aset terhadap optimalisasi pemanfaatan aset.

Hasil penelitian ini diharapkan dapat memberikan sumbangan pemikiran dan manfaat antara lain sebagai berikut : bagi Pemerintah Daerah Kabupaten Bone Bolango diharapkan dapat menjadi masukan dalam mendukung pelaksanaan pengelolaan barang milik daerah sesuai dengan ketentuan terutama yang menyangkut pemanfaatan aset daerah sehingga dapat dilakukan secara optimal dan dapat meningkatkan pendapatan daerah, serta diharapkan ke depannya pengelolaan aset daerah tidak lagi menjadi temuan dari BPK, bagi peneliti dapat menambah ilmu, wawasan dan pengetahuan peneliti mengenai aset daerah, khususnya mengenai proses inventarisasi, legal audit, penilaian dan kondisi aset serta pengaruhnya terhadap optimalisasi pemanfataan aset. Dan bagi akademisi diharapkan dapat memberikan kontribusi terhadap pengembangan literatur mengenai optimalisasi pemanfaatan aset daerah, dan selanjutnya dapat dijadikan sebagai acuan untuk penelitian lanjutan.

\section{Gambar 1. Kerangka Konseptual Penelitian}

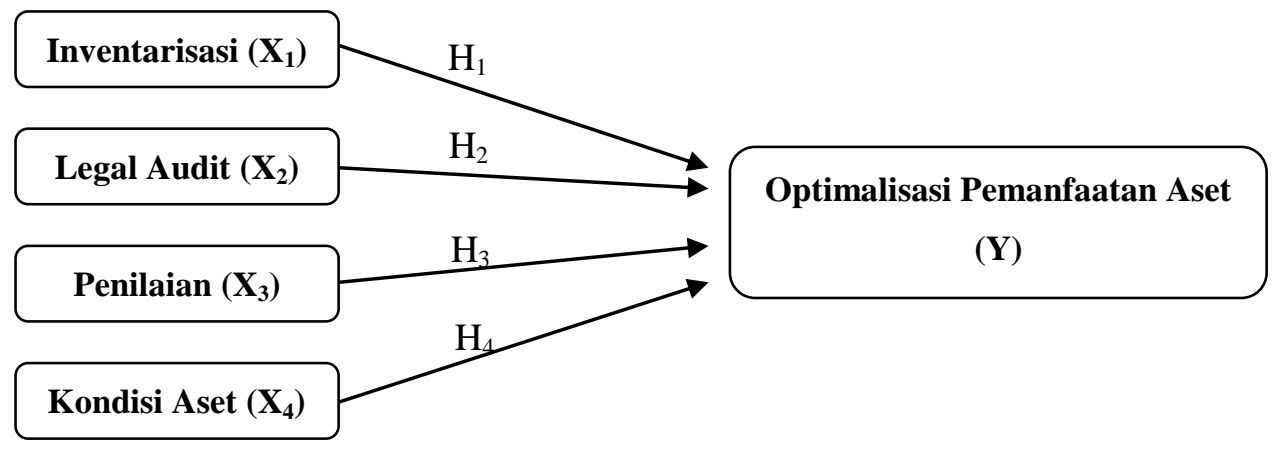

Berdasarkan landasan teori dan hasil-hasil penelitian terdahulu, maka hipotesa dalam penelitian ini dirumuskan menjadi empat hipotesa, antara lain:

\section{Pengaruh Inventarisasi terhadap Optimalisasi Pemanfaatan Aset}

Salah satu faktor yang menentukan munculnya niat untuk berperilaku adalah Behavioral Beliefs yakni keyakinan individu akan hasil dari suatu perilaku dan evaluasi atas hasil tersebut. Inventarisasi yang dalam prosesnya terdiri dari pendataan, pengkodean, pengelompokkan serta pembukuan yang tahapan kerjanya diatur oleh Permendagri Nomor 17 Tahun 2007 memberikan keyakinan kepada para pelakunya dalam hal ini Pengelola, Pengguna, Pembantu Pengelola, dan Pengurus BMD bahwa setelah kegiatan inventarisasi tersebut dilakukan, maka akan mendatangkan manfaat untuk pemda. Karena dengan inventarisasi data BMD menjadi lebih andal dan dapat dipertanggungjawabkan. Hal 
tersebut dapat dilihat dari barang yang ada di lapangan adalah sama dengan barang yang dicatat dan terdapat di laporan keuangan. Selain itu tentunya dapat memberikan kemudahan bagi pemda untuk melakukan pemanfaatan atas aset-aset yang ada, baik untuk tujuan dimanfaatkan oleh pemda untuk menunjang tugas pokok dan fungsi dalam menjalankan pemerintahan dan memberikan layanan yang prima kepada masyarakat, atau dapat pula untuk melakukan pemanfaatan aset secara optimal dengan cara disewakan kepada pihak ketiga. Murkana (1999) mengkaji tentang manajemen inventarisasi barang daerah di DKI Jakarta. Manajemen inventarisasi barang daerah dimaksudkan untuk memberikan data yang lengkap, valid dan mutakhir dalam bentuk daftar inventaris barang daerah guna menunjang kelancaran dan kemudahan dalam pemanfaatan dan pengelolaannya oleh Pemerintah Daerah. Perumusan hipotesa mengenai pengaruh inventarisasi terhadap optimalisasi pemanfaatan aset sebagai berikut:

$\mathrm{H}_{1}$ : Inventarisasi berpengaruh positif dan signifikan terhadap optimalisasi pemanfaatan aset.

\section{Pengaruh Legal Audit terhadap Optimalisasi Pemanfaatan Aset}

Salah satu unsur dari isi kebijakan tersebut adalah derajat perubahan yang diinginkan. Legal audit membawa pemda untuk lebih waspada dan lebih peka untuk melengkapi dokumen dan bukti kepemilikan dari aset-aset pemda. Pemda tentunya menginginkan agar aset-aset yang digunakan dan dimanfaatkan oleh pemda berada pada titik aman dan tidak memberikan peluang bagi pihak lain yang ingin menguasai aset tersebut dengan cara yang tidak bertanggungjawab. Pemda tentunya menginginkan perubahan ke arah yang lebih baik atas keabsahan dokumen-dokumen kepemilikan aset, dan diharapkan setiap tahunnya jumlah aset dengan dokumen kepemilikan lengkap semakin bertambah dan masalah mengenai pertikaian aset karena dokumen kepemilikan dengan pihak lain semakin kecil. Ebenezer and Dadson (2006) menganalisis pengoptimalan manajemen aset tanah di Ghana dalam rangka untuk melaksanakan good governance. Penelitian ini membahas mengenai administrasi yang efektif untuk aset-aset tanah yang vital, membahas seputar legislasi, dan organisasi yang berkaitan dalam sektor tanah, serta pemilik dan pengelola tanah harus saling berbagi tanggung jawab untuk menjamin pencapaian dari manajemen aset tanah. Perumusan hipotesa mengenai pengaruh legal audit terhadap optimalisasi pemanfaatan aset sebagai berikut:

$\mathrm{H}_{2}$ : Legal Audit berpengaruh positif dan signifikan terhadap optimalisasi pemanfaatan aset.

\section{Pengaruh Penilaian terhadap Optimalisasi Pemanfaatan Aset}

Salah satu unsur dari isi kebijakan yaitu sumber daya yang dikerahkan. Dukungan dari penilai independen berupa kompetensi mereka yang digunakan pada saat melakukan penilaian atas aset mendatangkan manfaat bagi kelangsungan aset tersebut. Saat ini di pemda banyak terdapat aset-aset yang tidak memiliki nilai sehingga dalam proses penggunaan dan pemanfaatannya tidak berjalan optimal, sehingga sangat diperlukan penilaian atas aset yang dilakukan oleh penilai yang memiliki kompetensi di bidang penilaian, sehingga aset-aset yang tadinya tidak memiliki nilai dapat menjadi memiliki nilai dan dapat segera digunakan atau dimanfaatkan. Yusuf Simunapendi (2015) menyatakan bahwa penilaian berpengaruh positif terhadap optimalisasi pemanfaatan aset tetap pada Kabupaten Waropen. Perumusan hipotesa mengenai pengaruh penilaian terhadap optimalisasi pemanfaatan aset sebagai berikut:

$\mathrm{H}_{3}$ : Penilaian berpengaruh positif dan signifikan terhadap optimalisasi pemanfaatan aset.

\section{Pengaruh Kondisi Aset terhadap Optimalisasi Pemanfaatan Aset}

Kondisi fisik aset adalah salah satu ukuran untuk menentukan kinerja dari aset. Suatu aset harus dapat digunakan secara aman dan efektif. Hal ini berarti bahwa aset perlu dipelihara agar berada dalam kondisi yang memadai untuk digunakan sesuai dengan tujuan yang telah ditetapkan dan memenuhi standar kesehatan dan keamanan yang relevan. Apabila aset tersebut tidak mengalami masalah, maka kemampuan aset untuk memberikan pelayanan akan sesuai dengan standar yang disyaratkan. Aset dapat digunakan dan dimanfaatkan secara optimal jika dalam kondisi baik. Aset milik pemda yang cenderung terbengkalai karena awalnya rusak ringan harus segera mendapatkan penanganan sehingga aset tersebut dapat kembali digunakan. Salah satu karakteristik dari Good Governance adalah efisien (berdaya guna) dan efektif (bernilai guna). Aset harus dapat disebut efektif dan efisien dalam penggunaan dan pemanfaatannya. Dan aset akan memenuhi keduanya jika dalam kondisi fisik yang baik, sehingga dapat digunakan dan dimanfaatkan secara optimal. Handayani (2007) menyatakan bahwa kondisi aset terbukti memiliki pengaruh terhadap pemanfaatan gelanggang remaja Kotamadya Jakarta Pusat. Penelitian lainnya dilakukan oleh Quertani, Parlikad, dan Mcfarlane (2008) yang menyatakan bahwa untuk mengembangkan strategi manajemen informasi aset yang efektif harus 
berfokus pada pengelolaan kumpulan informasi yang terkait dengan aset. Tujuan dari manajemen informasi aset itu sendiri adalah untuk menyediakan informasi yang tepat waktu, akurat, lengkap dan konsisten mengenai lokasi dan kondisi aset sehingga dapat menghasilkan pengambilan keputusan yang lebih baik.

\section{Metode Penelitian}

Jenis penelitian yang dilakukan adalah jenis penelitian kuantitatif. Populasi dari penelitian ini adalah Aparatur Sipil Negara (ASN) Pemerintah Daerah Kabupaten Bone Bolango yang terlibat dalam proses pengelolaan dan pemanfaatan Barang Milik Daerah (BMD), dan sampel dari penelitian ini adalah Pengelola BMD, Pembantu Pengelola BMD, Pengguna BMD serta Pengurus BMD. Total responden dalam penelitian ini sebanyak 104 orang. Teknik analisis data menggunakan uji asumsi normalitas dan uji asumsi klasik multikolinearitas dan uji heteroskedastisitas serta uji hipotesis yaitu uji statisitik t.

\section{Hasil dan Pembahasan}

Uji Normalitas. Berdasarkan hasil uji Kolmogorov-Smirnov diketahui nilai signifikansi lebih besar dari 0,05, yaitu sebesar 0,213. Dengan demikian dapat disimpulkan data dalam penelitian ini berdistribusi normal atau model regresinya layak digunakan. Hal ini dikarenakan memenuhi asumsi normalitas.

Tabel 1 Hasil Uji Kolmogorov - Smirnov

One Sample Kolmogorov Smirnov Test

\begin{tabular}{|c|c|c|}
\hline & & Unstandarddized Residual \\
\hline $\mathrm{N}$ & & $\begin{array}{ll}104 \\
\end{array}$ \\
\hline Normal Parameters ${ }^{\mathrm{a}, \mathrm{b}}$ & Mean & .0000000 \\
\hline & Standar Deviation & 2.45383851 \\
\hline Most Extreme Differences & Absolute & .104 \\
\hline & Positive & .054 \\
\hline & Negative & -.104 \\
\hline Kolmogorov-Smirnov Z & & 1.058 \\
\hline Asymp.Sig. (2-tailed) & & .213 \\
\hline
\end{tabular}

Uji Multikolinearitas. Nilai VIF dari semua variabel bebas juga berada di antara $1-10$, yaitu 2.309 untuk nilai variabel inventarisasi, nilai 1.701 untuk nilai variabel legal audit, nilai 2.121 untuk nilai variabel penilaian, dan nilai 1.357 untuk nilai variabel kondisi aset. Oleh karena itu, dapat disimpulkan bahwa tidak terjadi multikolinearitas dalam model regresi yang diteliti.

Tabel 2 Hasil Uji Multikolinearitas

\begin{tabular}{|c|c|c|c|c|c|c|c|}
\hline \multirow[t]{2}{*}{ Model } & \multicolumn{2}{|c|}{$\begin{array}{l}\text { Unstandardized } \\
\text { Coefficients }\end{array}$} & \multirow[t]{2}{*}{$\begin{array}{l}\text { Standardized } \\
\text { Coefficients }\end{array}$} & \multirow[t]{2}{*}{$\mathbf{t}$} & \multirow[t]{2}{*}{ Sig } & \multicolumn{2}{|c|}{ Colinearity Statistics } \\
\hline & B & $\begin{array}{c}\text { Std. } \\
\text { Error }\end{array}$ & & & & Tolerance & VIF \\
\hline 1 (Constant) & 4.989 & 2.014 & & 2.478 & .015 & & \\
\hline Inventarisasi & -.036 & .067 & -.080 & -.532 & .596 & .433 & 2.309 \\
\hline Legal Audit & -.056 & .047 & -.153 & -.1 .195 & .235 & .588 & 1.701 \\
\hline Penilaian & .094 & .103 & .131 & .918 & .361 & .472 & 2.121 \\
\hline Kondisi Aset & -.095 & .105 & -.103 & -.902 & .369 & .737 & 1.357 \\
\hline
\end{tabular}

Uji Heteroskedastisitas. Jika nilai signifikansi lebih besar dari 0,05 maka tidak terjadi heteroskedastisitas. Dalam penelitian ini seluruh variabel memiliki nilai signifikansi lebih dari 0,05. 
Tabel 3 Hasil Uji Gleyser

\begin{tabular}{|c|c|c|c|c|c|}
\hline \multicolumn{6}{|c|}{ Coefficients* } \\
\hline \multirow{2}{*}{ Model } & \multicolumn{2}{|c|}{ Unstandardized Coefficients } & \multirow{2}{*}{$\begin{array}{c}\begin{array}{c}\text { Standardized } \\
\text { Coefficients }\end{array} \\
\text { Beta }\end{array}$} & \multirow{2}{*}{$\mathbf{t}$} & \multirow{2}{*}{ Sig } \\
\hline & $\mathbf{B}$ & Std.Error & & & \\
\hline (Constant) & 4.989 & 2.014 & & 2.478 & 0.015 \\
\hline Inventarisasi & -0.036 & 0.067 & -0.080 & -0.532 & 0.596 \\
\hline Legal Audit & -0.056 & 0.047 & -0.153 & -1.195 & 0.235 \\
\hline Penilaian & 0.094 & 0.103 & 0.131 & 0.918 & 0.361 \\
\hline Kondisi Aset & -0.095 & 0.105 & -0.103 & -0.902 & 0.369 \\
\hline
\end{tabular}

Sumber: Hasil Olahan Sendiri, 2017 berikut:

Analisis Regresi. Hasil analisis regresi linier berganda dalam penelitian ini adalah sebagai $\mathrm{Y}=2.152+0,394 \mathrm{X}_{1}+0.063 \mathrm{X}_{2}+0.435 \mathrm{X}_{3}+0.502 \mathrm{X}_{4}+\mathrm{e}$

Adapun ringkasan hasil analisis regresi berganda dalam penelitian ini dapat dilihat pada Tabel 4 di bawah ini:

Tabel 4. Ringkasan Hasil Analisis Linier Berganda

\begin{tabular}{|c|c|c|c|}
\hline Nama Variabel & Beta & $\mathbf{t}_{\text {hitung }}$ & Sig \\
\hline (Constant) & 2.152 & 0.685 & 0.495 \\
\hline Inventarisasi & 0.394 & 3.771 & 0.000 \\
\hline Legal Audit & 0.063 & 0.867 & 0.388 \\
\hline Penilaian & 0.435 & 2.711 & 0.008 \\
\hline Kondisi Aset & 0.502 & 3.070 & 0.003 \\
\hline
\end{tabular}

Sumber: Hasil Olahan Sendiri, 2017

Uji Hipotesis 1: Inventarisasi berpengaruh positif terhadap optimalisasi pemanfaatan aset

Hasil pengujian hipotesis pertama $\left(\mathrm{H}_{1}\right)$ terkait pengaruh inventarisasi terhadap optimalisasi pemanfaatan aset menunjukkan nilai $\mathrm{t}_{\text {hitung }}>\mathrm{t}_{\text {tabel }}(3,771>1,98422)$. Nilai koefesien regresi sebesar 0,394 . Tingkat signifikansi sebesar 0,000 ( $\left.\mathrm{p}_{\text {value }}<0,05\right)$. Hal ini menunjukkan inventarisasi berpengaruh secara positif dan signifikan terhadap optimalisasi pemanfaatan aset.

Hasil pengujian ini sejalan dengan Teori Perilaku Terencana (Theory of Planned Behavior) menurut Ajzen dimana munculnya niat untuk berperilaku dalam Azwar (2013:13) ditentukan oleh tiga faktor, yaitu:

1. Behavioral Beliefs, merupakan keyakinan individu akan hasil dari suatu perilaku dan evaluasi atas hasil tersebut.

2. Normative Beliefs, merupakan keyakinan tentang harapan normatif orang lain dan motivasi untuk memenuhi harapan tersebut.

3. Control Beliefs, merupakan keyakinan tentang keberadaan hal-hal yang mendukung atau menghambat perilaku yang akan ditampilkan dan persepsinya tentang seberapa kuat hal-hal yang mendukung dan menghambat perilakunya tersebut (perceived power).

Salah satu faktor yang menentukan munculnya niat untuk berperilaku adalah Behavioral Beliefs yakni keyakinan individu akan hasil dari suatu perilaku dan evaluasi atas hasil tersebut. Inventarisasi yang dalam prosesnya terdiri dari pendataan, pengkodean, pengelompokkan serta pembukuan yang tahapan kerjanya diatur oleh Permendagri Nomor 17 Tahun 2007 memberikan keyakinan kepada para pelakunya dalam hal ini Pengelola, Pengguna, Pembantu Pengelola, dan Pengurus BMD bahwa setelah kegiatan inventarisasi tersebut dilakukan, maka akan mendatangkan manfaat untuk pemda. Karena dengan inventarisasi data BMD menjadi lebih andal dan dapat dipertanggungjawabkan. Hal tersebut dapat dilihat dari barang yang ada di lapangan adalah sama dengan barang yang dicatat dan terdapat di laporan keuangan. Selain itu tentunya dapat memberikan kemudahan bagi pemda untuk melakukan pemanfaatan atas aset-aset yang ada, baik untuk tujuan dimanfaatkan oleh pemda untuk menunjang tugas pokok dan fungsi dalam menjalankan pemerintahan dan memberikan layanan yang prima kepada masyarakat, atau dapat pula untuk melakukan pemanfaatan aset secara optimal dengan cara disewakan kepada pihak ketiga.

Siregar (2004:518-519) menyatakan bahwa inventarisasi aset terdiri dari dua aspek yaitu inventarisasi fisik dan yuridis/ legal. Aspek fisik terdiri atas bentuk, luas, lokasi, volume/jumlah, jenis, alamat, dan lain-lain. Sedangkan aspek yuridis adalah status penguasaan, masalah legal yang dimiliki, 
serta batas akhir penguasaan dan proses kerja yang dilakukan dalam inventarisasi aset adalah pendataan, kodifikasi/labelling, pengelompokan dan pembukuan/administrasi sesuai dengan tujuan manajemen aset. Peraturan Pemerintah Nomor 6 Tahun 2006 Tentang Pengelolaan Barang Milik Negara/Daerah menyatakan bahwa inventarisasi adalah kegiatan untuk melakukan pendataan, pencatatan dan pelaporan hasil pendataan barang milik daerah. Inventarisasi barang milik daerah dilakukan oleh pengguna barang sekurang-kurangnya lima (5) tahun sekali dan hasilnya dilaporkan kepada pengelola barang selambat-lambatnya tiga (3) bulan setelah selesai inventarisasi. Inventarisasi dilakukan untuk mendata aset yang ada di daerah untuk selanjutnya dilakukan pencatatan atas aset tersebut dan kemudian dilaporkan untuk kepentingan penyusunan Laporan BMD, dimana laporan tersebut akan menjadi bagian dari Laporan Keuangan Pemerintah Daerah. Selain itu laporan hasil inventarisasi juga memungkinkan pemerintah daerah untuk memiliki data mengenai aset yang bisa dimanfaatkan untuk menunjang tugas pokok dan fungsi dalam melayani masyarakat dan juga dimanfaatkan untuk disewakan kepada pihak lain (lebih dioptimalkan pemanfaatannya) untuk meningkatkan pendapatan daerah.

Yusuf (2013:27) menyatakan bahwa neraca daerah yang merupakan bagian dari laporan keuangan akan lengkap dan dapat dipercaya jika penatausahaan aset antara fisik aset, dokumen kepemilikan, dan penatausahaan dalam buku inventaris mempunyai kesesuaian. Dengan adanya alur penatausahaan yang sistematis maka tingkat kepercayaan terhadap proses penatausahaan akan selalu dapat dipercaya oleh siapapun yang membaca laporan keuangan tersebut. Lebih lanjut Yusuf (2013:35) menyatakan bahwa pelaksanaan penatausahaan dilakukan oleh bendahara barang dan petugas pencatat atau pejabat yang ditunjuk untuk mengelola aset/ BMD. Pencatatan dilakukan dalam rangka memberikan kepastian catatan atas setiap barang yang dibeli atau berubah keadaan karena terjadi mutasi maupun karena adanya pemusnahan, dan sebagai dasar dalam memberikan informasi kepada pihak-pihak yang memerlukan dalam rangka pelaksanaan akuntabilitas pengelolaan aset/ BMD secara transparan. Pihak-pihak yang memerlukan informasi mengenai aset tersebut salah satunya adalah pihak yang ingin memanfaatkan aset BMD, baik melalui penyewaan, pinjam pakai, kerjasama pemanfaatan, bangun guna serah maupun bangun serah guna.

Penelitian mengenai pengaruh inventarisasi terhadap optimalisasi aset pernah dilakukan Jusmin (2013) pada Pemerintah Kota Baubau dengan hasil penelitian inventarisasi berpengaruh positif dan signifikan terhadap optimalitas aset tetap (tanah dan bangunan), Erlini Nasution (2014) pada Rumah Sakit Jiwa Daerah Sumatera Utara dengan hasil penelitian inventarisasi berpengaruh positif dan signifikan terhadap optimalisasi aset. Penelitian ini menyarankan agar pihak rumah sakit perlu melakukan pengadaan alat kesehatan yang baru sehingga dapat mengganti alat-alat yang telah rusak agar dapat dipergunakan sesuai dengan kebutuhan. Selanjutynya Sri Fazatin (2013) pada pemda Jepara dengan hasil penelitian inventarisasi aset berpengaruh positif dan signifikan terhadap optimalisasi pemanfaatan aset, dan Yusuf Simunapendi (2015) pada Pemerintah Daerah Kabupaten Waropen dengan hasil penelitian inventarisasi mempunyai pengaruh positif dan signifikan terhadap pemanfaatan aset tetap. Penelitian lainnya dilakukan oleh Murkana (1999), beliau mengkaji tentang manajemen inventarisasi barang daerah di DKI Jakarta. Manajemen inventarisasi barnag daerah dimaksudkan untuk memberikan data yang lengkap, valid dan mutakhir dalam bentuk daftar inventaris barang daerah guna menunjang kelancaran dan kemudahan dalam pemanfaatan dan pengelolaannya oleh Pemerintah.

\section{Uji Hipotesis 2: Legal Audit berpengaruh positif terhadap optimalisasi pemanfaatan aset}

Hasil pengujian hipotesis kedua $\left(\mathrm{H}_{2}\right)$ terkait pengaruh legal audit terhadap optimalisasi pemanfaatan aset menunjukkan nilai $\mathrm{t}_{\text {hitung }}<\mathrm{t}_{\text {tabel }}(0,867<1,98422)$. Nilai koefesien regresi sebesar 0,063 . Tingkat signifikansi sebesar $0,388\left(\mathrm{p}_{\text {value }}>0,05\right)$. Hal ini menunjukkan legal audit tidak berpengaruh terhadap optimalisasi pemanfaatan aset.

Hasil pengujian ini tidak sejalan dengan Teori Implementasi Kebijakan menurut Grindle dimana keberhasilan implementasi dipengaruhi oleh isi kebijakan yang mencakup hal-hal sebahai berikut:

1. Kepentingan yang terpengaruhi oleh kebijakan

2. Jenis manfaat yang dihasilkan

3. Derajat perubahan yang diinginkan

4. Kedudukan pembuat kebijakan

5. Siapa pelaksana program

6. Sumber daya yang dikerahkan 
Salah satu isi kebijakan yang dimaksud adalah derajat perubahan yang diinginkan. Maksud dari derajat perubahan yang diinginkan adalah dengan adanya legal audit, maka pemda menginginkan adanya perubahan pandangan dan pemahaman akan pentingnya bukti-bukti dan dokumen kepemilikan guna menunjang keamanan penggunaan dan pemanfaatan aset yang ada di pemda. Untuk aset tanah ditetapkan standarnya yaitu harus memiliki status kepemilikan berbentuk sertifikat, untuk aset kendaraan bermotor harus memiliki bukti kepemilikan berbentuk Bukti Kepemilikan Kendaraan bermotor (BPKB), dan untuk gedung dan bangunan dilengkapi dengan Izin Mendirikan Bangunan (IMB).

Selain itu pelaksanaan legal audit juga berujung pada kepastian hukum. Hasil dari pengujian ini juga tidak sejalan dengan teori Good Governance menurut UNDP. Beberapa karakteristik pelaksanaan good governance, diantaranya:
1. Participation
2. Rule of Law
3. Transparency
4. Responsiveness
5. Consensus Orientation
6. Equity
7. Efficiency and Effectiveness
8. Accountability

Salah satu prinsip dari Good Governance adalah kepastian hukum. Dengan aset yang legal, memiliki status kepemilikan yang jelas secara langsung memberikan kepastian hukum atas aset tersebut. Hal ini sangat diperlukan untuk menghindari sengketa dan penyerobotan dari pihak-pihak yang tidak bertanggung jawab dan ingin menguasai aset milik pemda. Permendagri Nomor 17 Tahun 2007 menyatakan bahwa pengelola, pengguna dan/atau kuasa pengguna wajib melakukan pengamanan BMD yang berada dalam penguasaannya. Salah satu jenis pengamanan yang dimaksud adalah pengamanan hukum, yang antara lain meliputi kegiatan melengkapi bukti status kepemilikan. Hasil dari penelitian yang menyatakan legal audit tidak berpengaruh terhadap optimalisasi pemanfaatan aset ini tidak sejalan dengan Permendagri Nomor 17 tahun 2007 yang menyatakan bahwa BMD yang ada dalam penguasaan pemda harus memiliki bukti status kepemilikan agar aman secara hukum, dalam artian tidak memungkinkan adanya penyerobotan ataupun sengketa dengan pihak lain. Karena BMD dengan status dan bukti kepemilikan yang jelas akan membuka peluang pemanfaatan untuk disewakan atau dikerjasamakan dengan pihak ketiga yang lebih optimal.

Legal audit menurut Siregar (2004:519) merupakan satu lingkup kerja manajemen aset yang berupa inventarisasi status penguasaan aset, sistem dan prosedur penguasaan atas pengalihan aset, identifikasi dan mencari solusi atas permasalahan legal dan strategi untuk memecahkan berbagai permasalahan legal yang terkait dengan penguasaan ataupun pengalihan aset. Permasalahan legal yang sering ditemui antara lain status hak penguasaan yang lemah, aset dikuasai pihak lain, pemindahtanganan aset yang tidak termonitor, dan lain-lain. Umumnya aset yang ada di daerah masih memiliki masalah dengan status serta bukti kepemilikannya. Tak jarang hal tersebut membuat aset lepas dari tangan pemerintah daerah. Dalam hal ini pemerintah daerah seharusnya mendeteksi dan menjaga lebih awal kemungkinan-kemungkinan yang akan timbul jika aset daerah tidak disertai bukti kepemilikan yang jelas. Aset dengan status kepemilikan yang jelas seharusnya lebih memberikan rasa aman pada saat penggunaan maupun pemanfaatannya. Namun dalam penelitian ini legal audit tidak berpengaruh terhadap optimalisasi pemanfaatan aset, dalam artian pemahaman sebagian besar responden yaitu aset tetap dapat digunakan dan dimanfaatkan walaupun beresiko untuk diserobot oleh pihak lain karena tidak memiliki bukti kepemilikan yang jelas dan sah menurut hukum.

Penelitian dengan hasil berbeda pernah dilakukan oleh Ary Wahyuni (2012) dengan judul "Pengaruh Manajemen Aset terhadap Optimalisasi Pemanfaatan Aset Tetap Pemerintah Kabupaten Sumbawa Barat", dimana hasil penelitiannya menyatakan bahwa legal audit berpengaruh positif terhadap optimalisasi pemanfaatan aset tetap. Sementara penelitian dengan hasil yang sama berasal dari Jamaludin (2013) pada Pemda Provinsi Nusa Tenggara Barat (NTB) dengan hasil penelitian legal audit tidak berpengaruh terhadap optimalisasi pengelolaan dan pemanfaatan aset tetap (tanah dan bangunan). Hasil analisis Data Envelopment Analysis (DEA) menunjukkan dari 17 SKPD yang ditetapkan sebagai lembaga teknis daerah yang memiliki target pencapaian pendapatan asli daerah hanya terdapat 6 SKPD saja yang efisien dalam mengelola dan memanfaatkan aset tetap (tanah dan bangunan dengan nilai efisien relatif sebesar $100 \%$. Selain itu, Elsye Beatrik Bles (2015) pada 
Pemerintah Kota Jayapura dengan hasil penelitian legal audit tidak berpengaruh terhadap optimalisasi aset tetap (tanah dan bangunan).

\section{Uji Hipotesis 3: Penilaian berpengaruh positif terhadap optimalisasi pemanfaatan aset}

Hasil pengujian hipotesis ketiga $\left(\mathrm{H}_{3}\right)$ terkait pengaruh penilaian terhadap optimalisasi pemanfaatan aset menunjukkan nilai $\mathrm{t}_{\text {hitung }}>\mathrm{t}_{\text {tabel }}(2,711>1,98422)$. Nilai koefesien regresi sebesar 0,435 . Tingkat signifikansi sebesar $0,008\left(p_{\text {value }}<0,05\right)$. Hal ini menunjukkan penilaian berpengaruh secara positif dan signifikan terhadap optimalisasi pemanfaatan aset. Dalam proses penilaian juga diperlukan dukungan dari pihak lain, yaitu penilai independen. Hal ini sejalan dengan teori implementasi kebijakan menurut Grindle, dimana keberhasilan implementasi dipengaruhi oleh isi kebijakan. Adapun Isi kebijakan tersebut mencakup hal-hal sebagai berikut:

1. Kepentingan yang terpengaruhi oleh kebijakan

2. Jenis manfaat yang dihasilkan

3. Derajat perubahan yang diinginkan

4. Kedudukan pembuat kebijakan

5. Siapa pelaksana program

6. Sumber daya yang dikerahkan

Salah satu unsur dari isi kebijakan yaitu sumber daya yang dikerahkan. Dukungan dari penilai independen berupa kompetensi mereka yang digunakan pada saat melakukan penilaian atas aset mendatangkan manfaat bagi kelangsungan aset tersebut. Saat ini di pemda banyak terdapat aset-aset yang tidak memiliki nilai sehingga dalam proses penggunaan dan pemanfaatannya tidak berjalan optimal, sehingga sangat diperlukan penilaian atas aset yang dilakukan oleh penilai yang memiliki kompetensi di bidang penilaian, sehingga aset-aset yang tadinya tidak memiliki nilai dapat menjadi memiliki nilai dan dapat segera digunakan atau dimanfaatkan. Penilaian menurut Hidayati (2015:13) adalah sebuah penganggaran/ estimasi nilai dari sesuatu kepentingan ke atas sebuah properti/ harta untuk sesuatu tujuan tertentu. Sedangkan menurut Peraturan Menteri Dalam Negeri Nomor 17 Tahun 2007 Tentang Pedoman Teknis Pengelolaan Barang Milik Daerah, penilaian barang milik daerah dilakukan dalam rangka penyusunan neraca pemerintah daerah, pemanfaatan dan pemindahtangan barang milik daerah. Penilaian barang milik daerah dilaksanakan oleh tim yang ditetapkan oleh Kepala Daerah dan dapat melibatkan penilai independen yang bersertifikat di bidang penilaian aset.

Salah satu tujuan dilakukannya penilaian adalah untuk pemanfaatan aset. Dalam hal ini aset yang dimanfaatkan (disewakan) kepada pihak ketiga terlebih dahulu harus memiliki nilai yang jelas dan wajar, sehingga dalam proses penyewaannya nilai yang akan didapatkan dapat sesuai dengan kegunaan yang diberikan oleh aset tersebut. Aset yang dimanfaatkan melalui penyewaan maupun kerjasama dengan pihak lain akan mendatangkan pendapatan bagi daerah. Dukungan dari penilai independen berupa kompetensi mereka yang digunakan pada saat melakukan penilaian atas aset untuk hasil penilaian diharapkan memberikan hasil yang akuntabel dan transparan. Hal ini sejalan dengan teori Good Governanace dari UNDP, dimana prinsip-prinsip yang harus dipenuhi agar tercipta Good Governance adalah harus transparan dan akuntabel. Siregar (2016:107) menyatakan bahwa salah satu faktor yang menyebabkan aset atau sumberdaya atau potensi daerah belum terkelola dan termanfaatkan secara maksimal adalah masalah penilaiannya yang belum benar. Bahkan, dapat dibilang lebih banyak aset daerah yang belum tersentuh oleh penilaian. Padahal, hasil penilaian inilah yang akan dijadikan dasar untuk melakukan perbaikan pengelolaan aset daerah sehingga dapat dimanfaatkan secara maksimal. Teori ini sejalan dengan hasil penelitian yang menyatakan bahwa penilaian berpengaruh terhadap optimalisasi pemanfaatan aset.

Penelitian ini didukung oleh penelitian yang pernah dilakukan oleh Yusuf Simunapendi (2015) mengenai pengaruh penilaian terhadap optimalisasi pemanfaatan aset tetap pada Pemerintah Daerah Kabupaten Waropen dengan hasil penelitian penilaian mempunyai pengaruh positif dan signifikan terhadap pemanfaatan aset tetap. Anshari (2016) dengan variabel Y yang berbeda pada Pemerintah Kota Padang dengan hasil penelitian penilaian mempunyai pengaruh positif dan signifikan terhadap kualitas laporan keuangan, serta Endang Widayanti (2010) pada Pemda Kabupaten Sragen dengan hasil penelitian penilaian berpengaruh terhadap optimalisasi aset. Sedangkan penelitian dengan hasil yang berbeda pernah dilakukan oleh Emma Seroja Ayomi (2014) dengan judul "Pengaruh Manajemen Aset terhadap Optimalisasi Aset Tetap (Tanah dan Bangunan) Pemerintah daerah (Studi di Kabupaten Manokwari)". Hasil penelitiannya menyatakan bahwa penilaian tidak terbukti memiliki pengaruh yang signifikan terhadap optimalisasi aset tetap (tanah dan bangunan). 


\section{Uji Hipotesis 4: Kondisi Aset berpengaruh positif terhadap optimalisasi pemanfaatan aset}

Hasil pengujian hipotesis keempat $\left(\mathrm{H}_{4}\right)$ terkait pengaruh kondisi aset terhadap optimalisasi pemanfaatan aset menunjukkan nilai $t_{\text {hitung }}>t_{\text {tabel }}(3,070>1,98422)$. Nilai koefesien regresi sebesar 0,502 . Tingkat signifikansi sebesar $0,003\left(\mathrm{p}_{\text {value }}<0,05\right)$. Hal ini menunjukkan kondisi aset berpengaruh secara positif dan signifikan terhadap optimalisasi pemanfaatan aset. Kondisi fisik aset adalah salah satu ukuran untuk menentukan kinerja dari aset. Suatu aset harus dapat digunakan secara aman dan efektif. Hal ini berarti bahwa aset perlu dipelihara agar berada dalam kondisi yang memadai untuk digunakan sesuai dengan tujuan yang telah ditetapkan dan memenuhi standar kesehatan dan keamanan yang relevan. Apabila aset tersebut tidak mengalami masalah, maka kemampuan aset untuk memberikan pelayanan akan sesuai dengan standar yang disyaratkan. Aset dapat digunakan dan dimanfaatkan secara optimal jika dalam kondisi baik. Aset milik pemda yang cenderung terbengkalai karena awalnya rusak ringan harus segera mendapatkan penanganan sehingga aset tersebut dapat kembali digunakan. Hal ini sejalan dengan Teori Good Governance menurut UNDP yang menyatakan bahwa karakteristik dari Good Governance diantaranya adalah:

\section{Participation \\ 2. Rule of Law \\ 3. Transparency \\ 4. Responsiveness \\ 5. Consensus Orientation \\ 6. Equity \\ 7. Efficiency and Effectiveness \\ 8. Accountability}

Salah satu karakteristik dari Good Governance adalah efisien (berdaya guna) dan efektif (bernilai guna). Aset harus dapat disebut efektif dan efisien dalam penggunaan dan pemanfaatannya. Dan aset akan memenuhi keduanya jika dalam kondisi fisik yang baik, sehingga dapat digunakan dan dimanfaatkan secara optimal. Modul Prinsip dan Teknik Manajemen Kekayaan Negara Departemen Keuangan Republik Indonesia (2007) menyatakan bahwa terdapat beberapa ukuran yang digunakan untuk menentukan kinerja aset, antara lain:

1. Kondisi fisik aset

2. Pemanfaatan aset

3. Fungsionalisasi aset

4. Kinerja finansial aset

Kondisi fisik aset adalah salah satu ukuran untuk menentukan kinerja dari aset. Suatu aset harus dapat digunakan secara aman dan efektif. Hal ini berarti bahwa aset perlu dipelihara agar berada dalam kondisi yang memadai untuk digunakan sesuai dengan tujuan yang telah ditetapkan dan memenuhi standar kesehatan dan keamanan yang relevan. Apabila aset tersebut tidak mengalami masalah, maka kemampuan aset untuk memberikan pelayanan akan sesuai dengan standar yang disyaratkan. Teori di atas sejalan dengan hasil penelitian yang menyatakan bahwa kondisi aset berpengaruh terhadap optimalisasi pemanfaatan aset.

Penelitian mengenai pengaruh kondisi aset terhadap optimalisasi pemanfaatan aset pernah dilakukan oleh Handayani (2007) dengan judul "Faktor-faktor yang Mempengaruhi Pemanfaatan Aset Tanah dan Bangunan Gelanggang Remaja Kotamadya Jakarta Pusat". Hasil penelitiannya menyatakan bahwa kondisi aset terbukti memiliki pengaruh terhadap pemanfaatan gelanggang remaja Kotamadya Jakarta Pusat. Penelitian lainnya dilakukan oleh Quertani, Parlikad, dan Mcfarlane (2008) yang menyatakan bahwa untuk mengembangkan strategi manajemen informasi aset yang efektif harus berfokus pada pengelolaan kumpulan informasi yang terkait dengan aset. Tujuan dari manajemen informasi aset itu sendiri adalah untuk menyediakan informasi yang tepat waktu, akurat, lengkap dan konsisten mengenai lokasi dan kondisi aset sehingga dapat menghasilkan pengambilan keputusan yang lebih baik.

\section{Penutup}

Penelitian ini bertujuan untuk menguji secara positif dan signifikan pengaruh inventarisasi, legal audit, penilaian dan kondisi aset terhadap optimalisasi pemanfaatan aset pada Pemerintah Daerah Kabupaten Bone Bolango. Hasil penelitian ini menyimpulkan bahwa:

1. Inventarisasi berpengaruh positif dan signifikan terhadap optimalisasi pemanfaatan aset pada Pemerintah Daerah Kabupaten Bone Bolango. Hal ini berarti bahwa semakin baik inventarisasi 
yang dilakukan oleh pemerintah daerah Kabupaten Bone Bolango maka pemanfaatan aset akan semakin baik dan optimal.

2. Legal audit tidak berpengaruh terhadap optimalisasi pemanfaatan aset pada Pemerintah Daerah Kabupaten Bone Bolango. Hal ini disebabkan kurangnya pemahaman para pihak yang terkait dengan barang milik daerah mengenai pentingnya status dan bukti kepemilikan atas aset daerah. Dengan status dan bukti yang kuat atas kepemilikan aset daerah seharusnya dapat lebih mengoptimalkan penggunaan serta pemanfaatan aset tersebut. Pemerintah daerah masih belum maksimal dalam melakukan legal audit atas aset yang ada.

3. Penilaian berpengaruh positif dan signifikan terhadap optimalisasi pemanfaatan aset pada Pemerintah Daerah Kabupaten Bone Bolango. Hal ini berarti bahwa semakin baik penilain atas aset yang dilakukan oleh pemerintah daerah Kabupaten Bone Bolango maka pemanfaatan aset akan semakin baik dan optimal.

4. Kondisi aset berpengaruh positif dan signifikan terhadap optimalisasi pemanfaatan aset pada Pemerintah Daerah Kabupaten Bone Bolango. Hal ini berarti bahwa semakin baik kondisi atas aset yang dimiliki oleh pemerintah daerah Kabupaten Bone Bolango maka pemanfaatan aset akan semakin baik dan optimal. berikut:

Saran yang dapat diberikan berdasarkan hasil penelitian yang telah dilakukan adalah sebagai

1. Pemerintah Daerah khususnya Sekretaris daerah (Sekda) selaku Pengelola BMD beserta BKPD selaku Pembantu Pengelola BMD, Kepala Dinas/Bagian/Kantor/Badan dan Camat selaku Pengguna BMD dan Bendahara Barang selaku Pengurus BMD dapat rutin melakukan inventarisasi atau sensus BMD dalam lima (5) tahun sekali, sehingga data mengenai BMD (baik dalam penggunaan maupun pemanfaatannya) dapat lebih andal dan dapat dipertanggungjawabkan.

2. Pemerintah Daerah khususnya Sekretaris daerah (Sekda) selaku Pengelola BMD beserta BKPD selaku Pembantu Pengelola BMD, Kepala Dinas/Bagian/Kantor/Badan dan Camat selaku Pengguna BMD dan Bendahara Barang selaku Pengurus BMD dapat lebih serius dalam menyikapi bukti dan status kepemilikan aset daerah guna menghindari penyerobotan dari pihakpihak yang tidak bertanggungjawab,

3. Pemerintah Daerah khususnya Sekretaris daerah (Sekda) selaku Pengelola BMD dapat memberikan rekomendasi bagi BKPD selaku Pembantu Pengelola BMD serta Bendahara Barang selaku Pengurus BMD untuk mengikuti pelatihan atas penilaian aset, sehingga ke depannya Pemerintah Daerah tidak menggunakan jasa penilai independen dalam menilai aset daerahnya.

4. Pemerintah Daerah khususnya Sekretaris daerah (Sekda) selaku Pengelola BMD beserta BKPD selaku Pembantu Pengelola BMD, Kepala Dinas/Bagian/Kantor/Badan dan Camat selaku Pengguna BMD dan Bendahara Barang selaku Pengurus BMD secara rutin memantau kondisi aset-aset yang ada di pemda, sehingga tidak terdapat aset yang tidak digunakan atau tidak dimanfaatkan (idle).

5. Bagi akademis diharapkan dapat memberikan kontribusi terhadap peneliti selanjutnya untuk menguji variabel lain yang bisa mempengaruhi optimalisasi pemanfaatan aset, mulai dari sistem informasi dan pengawasan serta pengendalian.

\section{Daftar Pustaka}

Azwar, Saifuddin, 2013. Sikap Manusia (Teori dan Pengukurannya). Yogyakarta: Pustaka Pelajar. Ayumi, Seroja Emma. 2014. Pengaruh Manajemen Aset terhadap Optimalisasi Aset Tetap (Tanah dan Bangunan) Pemerintah Daerah (Studi di Kabupaten Manokwari). Universitas Gajah Mada: Tesis.

Bles, Beatrix Elsye, 2015. Analisis Faktor-Faktor yang Mempengaruhi Pengelolaan Aset Tetap (Tanah dan Bangunan): Studi pada Pemerintah Daerah Kota Jayapura. Universitas Gajah Mada: Tesis.

Dadson and Kobina Ebenezer. 2006. Optimizing Land Asset Management in Ghana a Shared Responsibility and Recipe for Good Governance. XXIII FIG Congress Munich, Germany.

Fazatin, Sri. 2013. Analisis Faktor Optimalisasi Pemanfaatan Aset Tetap Pemerintah Daerah Jepara. Universitas Islam Nahdlatul Ulama: Tesis.

Handayani, Yuli Lilik. 2007. Faktor-faktor Yang Mempengaruhi Pemanfaatan Aset Tanah Dan Bangunan Gelanggang Remaja Kotamadya Jakarta Pusat. Universitas Indonesia: Tesis.

Hidayati, Wahyu \& Harjanto, Budi. 2015. Konsep Dasar Penilaian Properti (Edisi Kedua). Yogyakarta: BPFE. 
Jamaludin. 2013. Optimalisasi Pengelolaan dan Pemanfaatan Aset Tetap Tanah (Tanah dan Bangunan) studi pada Pemda Provinsi NTB. Universitas Gajah Mada: Tesis.

Jusmin. 2013. Pengaruh Manajemen Aset Terhadap Tingkat Optimalitas Aset Tetap (Tanah dan Bangunan) Pemerintah Kota Baubau. Universitas Gajah Mada: Tesis.

Murkana. 1999. Manajemen Inventarisasi Barang Daerah (Studi Kasus: Pengelolaan/ Inventarisasi Aset (Barang) milik/ dikuasai Pemerintah Daerah Khusus Ibukota Jakarta). Universitas Gajah Mada: Tesis.

Nasution, Erlini. 2014. Pengaruh Manajemen Aset Terhadap Optimalisasi Aset Rumah Sakit Jiwa Daerah Provinsi Sumatera Utara. Pasca Sarjana Universitas Sumatera Utara: Tesis.

Quertani, Parlikad, Mcfarlane. 2008. Towards an Approach to Select an Asset Information Management Strategy. International Journal of Computer Science and Applications, Vol.5 No.3b, pp 25-44.

Republik Indonesia. 2007. Peraturan Menteri Dalam Negeri Nomor 17 Tahun 2007 Tentang Pedoman Teknis Pengelolaan Barang Milik Daerah.

Republik Indonesia. 2004. Undang-Undang Nomor I Tahun 2004 Tentang Perbendaharaan Negara.

Republik Indonesia. 2007. Modul Prinsip dan Teknik Manajemen Kekayaan Negara, Departemen Keuangan Republik Indonesia.

Simunapendi, Yusuf. 2015. Pengaruh Faktor-faktor Manajemen Aset Tetap Terhadap Pemanfaatan (Tanah dan Bangunan) Pemerintah Daerah (Studi Kasus Kantor Bupati Kabupaten Waropen). Universitas Gajah Mada: Tesis.

Siregar, Doli D. 2004. Manajemen Aset Strategi Penataan Konsep Pembangunan Berkelanjutan Secara Nasional Dalam Konteks Kepala Daerah Sebagai CEO's Pada Era Globalisasi dan Otonomi Daerah. Jakarta: PT Gramedia Pustaka Utama.

Widayanti, Endang. 2016. Pengaruh Manajemen Aset terhadap Optimalisasi Pemanfaatan Aset Tetap Pemerintah Daerah. Universitas Sebelas Maret Surakarta : Tesis.

Yusuf, M. 2013. 8 Langkah Pengelolaan Aset Daerah. Jakarta: Salemba Empat. 